\title{
ON A NEW SPECIES OF ACTINOPHORUS FROM MADAGASCAR.
}

\author{
BY JOHN W. SHIPP.
}

\section{Actinophorus grandidieri sp. nov.}

$D^{4}$

ARK fuscous, with a greenish tinge and reflection. anterior margin reflexed; very thickly and closely punctured, the punctures being much coarser and run together round the margins; teeth rather pointed and impunctate. Two transverse carinae extend from the eyes towards the centre of the head, but disappear on disc. Head slightly raised on disc between the carinae, and a rather deep cleft separates the basal teeth of the clypeus from the others; a small patch of short pitchy brown hairs are situated in the lobes of the four front teeth.

Thorax very thickly and closely punctured with rather deep well-defined punctures, and with a slight trace of a longitudinal smooth line on disc, which, however, is sometimes quite obsolete. Lateral margins rounded; anterior angles sharply obtuse, posterior angles being almost obsolete; lateral margins deeply crenulated the whole length and furnished with a row of pitchy hairs ; anterior margin finely and smoothly emarginate. Posterior margin crenulate the whole length, with the exception of a small portion adjoining the scutellary region; scutellary projection obsolete. Lateral cicatrices obsolete.

Elytra finely granulo-asperate, with some moderately large shallow pores scattered over the interstices. Elytra six-striate, with the striae composed of a number of shallow pores run together, giving the striae the appearance of being quite smooth. Sides rounded, scarcely cordate, rather depressed on disc; lateral margins strongly emarginate, bicarinate, and smooth. Humeral prominences not very distinct.

Pygidium emarginate, twice as wide as long, and very sparingly punctured.

Anterior and posterior femora smooth, with a few large punctures scattered over the thick portions and margins, the punctures being furnished with short light brown hairs.

Anterior tibiae four-dentate; disc impunctate, but with a raised crenulated carina which terminates in a short raised tooth at the base of the basal tooth, the carina being provided with a row of short porrect hairs. The indentations between the teeth on the exterior margin are scalloped.

Posterior tibiae long, curved, and fringed with short hairs; posterior coxae produced into a short sharp spine.

Abdomen almost impunctate on disc, rather finely punctured at sides.

Mesosternum almost impunctate, a small longitudinal depression on disc, and produced to an obtuse impunctate keel, which is thickly punctured on the sides and sparingly furnished with short pitchy hairs. 
Mesothorax almost impunctate, with a number of fine long pitchy hairs on the lower surface.

Long. corp. $20-22 \mathrm{~mm}$.

Hab. S.W. Madagasear.

Type in the Tring Museum.

Mons. Kunkel D'Hereulais figures an Actinophorus in Grandidier's Hist. Nat. de Madagascar (Col.), Vol. II. Pt. I. Pl. 17. f. 1, which he calls Ateuchus radama. The above insect, however, differs from the poorly executed figure of D'Herculais in having four teeth on the exterior margin of the anterior tibiae and is of a much greener hue. As a large number of the Coproplaga figured in the above work are quite unrecognisable, I think it would be far more convenient and canse less confusion if D'Herculais' names were dropped altogether.

\section{ON SOME NEW SUBSPECIES OF PAPILIO.}

By THE HON. WALTER ROTHSCHILD.

\section{Papilio alcinous loochooanus subsp. nov.}

8. This form combines in colour and structure the characters of the Japanese alcinous alcinous Klng and the Chinese alcinous confusus Rothsch. The front of the head is clothed with red and black hairs as in confusus; the submarginal spots to the underside of the hindwing are shaped as in alcinous, those between the discoidal and median veins being less arched than in the Chinese form. The colour of the spots varies from bright red to pale pink ; sometimes the spots are marked on the upperside. The harpe (see Nov. ZooL. 1895. t. VI.) agrees with that of the Japanese form.

Hab. Okinawa, Loo Choo Islands.

\section{Papilio coon palembanganus subsp. nov.}

8. Upperside: the subcostal and discocellular veins of the hindwing a little more broadly black than in coon coon F., the two white spots near the apex of the cell between veins 3 and 5 absent; two submarginal spots only marked, one between veins 5 and 6 , ovate, situated nearly $4 \mathrm{~mm}$. from the margin; the other between veins 4 and 5 , lunate, $5 \mathrm{~mm}$. from the margin of the wing; the first and two last submarginal spots of coon coon are absent; the marginal spots at the end of veins 2 and 3 yellow as in coon coon, somewhat smaller.

Underside: all the spots of the Javan coon present in the Sumatran form; the discal spot between veins 4 and 5 is minute; the first and two last white submarginal spots are smaller than in coon coon, the last joined to the marginal spot by means of a thin line.

Hab. Upper Musi River, Palembang district, Sumatra; $103^{\circ}$ E. Long., $3^{\circ}$ S. Lat. 


\section{$2 \mathrm{BHL}$ Biodiversity Heritage Library}

Shipp, John W. 1896. "On a new species of Actinophorus from Madagascar." Novitates zoologicae : a journal of zoology in connection with the Tring Museum 3, 420-421. https://doi.org/10.5962/bhl.part.5428.

View This Item Online: https://www.biodiversitylibrary.org/item/22554

DOI: https://doi.org/10.5962/bhl.part.5428

Permalink: https://www.biodiversitylibrary.org/partpdf/5428

\section{Holding Institution}

Natural History Museum Library, London

\section{Sponsored by}

Natural History Museum Library, London

\section{Copyright \& Reuse}

Copyright Status: Public domain. The BHL considers that this work is no longer under copyright protection.

This document was created from content at the Biodiversity Heritage Library, the world's largest open access digital library for biodiversity literature and archives. Visit BHL at https://www.biodiversitylibrary.org. 